\title{
Profile of Student Life Skills on Environmental Change Problems on the topic of Waste Recycling
}

\author{
Santi, Widi Purwianingsih, Yayan Sanjaya \\ Departemen Pendidikan Biologi, Sekolah Pascasarjana \\ Universitas Pendidikan Indonesia \\ Bandung, Indonesia \\ shantysept14@gmail.com
}

\begin{abstract}
Life skills is one of the skills or ability to solve a problem. Life skills of academic skills is one that students need in solving problems one of them in everyday life. This study aims to analyze student's life skills by using three indicators on academic ability: identifying and connecting variables, mastering knowledge, and thinking strategically. This research uses a descriptive method. Data collection is done by giving a questionnaire of academic proficiency about environmental changes on the topic of waste recycling to students in one of the SMA Negeri in Karawang West Java. The results showed that the academic skills in the indicators identify and connect the variables have an average of 2.90 with the medium category, the indicator has knowledge of the average of 2.79 with the medium category, while the indicator of strategic thinking has an average of 3.26 with high category, student academic skills still need to be improved again.
\end{abstract}

Keywords—life skills; academic skills; environmental changes; waste recycling

\section{INTRODUCTION}

Life skills are a skill that can equip students to solve problems in their daily lives effectively. Therefore, life skills need to be developed in education. Education life skills is an education that can equip students to be proficient in solving a life and life problems. In harmony with King's statement that life skills in education have the primary goal of providing students with skills and information on issues affecting their lives. Life skills are self-development to survive, grow and develop so as to have the ability to communicate and connect both individually, in groups and through systems in the face of certain situations.

Life skills are an important aspect that needs to be developed in shaping students into individuals who are ready to run their lives (Dailey, Conroy, \& Shelley-Tolbert, 2001). Through the development of skills or life skills it is able to assist students in developing self-esteem and competence in learning to work with others, able to express their feelings, solve problems and welcome new experiences (Rosen in Junge et al, 2003), helping students become individuals who have potential in their work, contribute to success and become an independent person in the future (Cronin, 1996), as well as helping students to better understand themselves, characteristics, wants, goals, strength, passion, value and their identity .
The concept of life skills in schools is a curriculum development discourse that has long been a concern by curriculum experts. The research conducted by Tuttle, Campbel-Heider, \& David, (2004) regarding the addition of life skills into the student curriculum shows the adolescent's extraordinary ability to speak and flexibility. In order for the development of life skills in students to develop well should be on learning using methods that in life skills teaching built on what is known about how students learn from their own experiences and from those around them, from observing how others behave and what consequences arising from behavior, these are described in the Social Learning Theory developed by Bandura (1977). World Health Organization (1997) also states that childhood and adolescence is a period of development in which a person acquires skills through various methods and people. Therefore, there needs to be an extraordinary emphasis on student's life skills.

Life Skills have indicators that serve to see achievements in life skills and as a basis for developing assessment tools. Depdiknas (2003) shares some life skills indicators such as academic skills that are based on the development of rational thinking skills, academic skills have been directed toward scientific or academic activities, identifying and connecting variables, mastering knowledge, and thinking strategically. Some factors of students who have academic skills other than active learning (Sarwar, Bashir, Khan, \& Khan, 2009), also because of well-educated parents and good parenting (Burchinal, Peisner-Feinberg, Pianta, \& Howes, 2002), but not all students feel that so not all students have the skills academic high.

ACTE states that all high school students need the necessary academic skills to continue their education, so that academic skills are necessary to be developed in education, in addition to continuing education students also have hope for success and have higher presistence (Jabeen \& Khan, 2013). Assessment in the life skills of internal class in the classroom, where there are student assessments conducted by teachers in the classroom at a certain level at the time and the end of learning, so it can be known the development and skills of student life skills (Depdiknas, 2003). Assessment in life skills is made to assess the life skills possessed by each student, one of them by measuring through the scale of life skills assessment with various dimensions of scale. 


\section{METHOD}

\section{A. Method of Data Collecting}

The data collection was conducted by giving life skills questionnaire instruments that focused on indicators of academic skills regarding environmental changes and waste recycling. The questionnaire instrument was given to 35 students in one of the SMA Negeri in Karawang West Java. The questionnaire instrument for measuring students' academic skills consists of 6 statements representing each indicator of academic skills. The questionnaire instrument on the academic skills used has been validated by expert lecturers. Scores obtained by students on each statement illustrate the achievement of academic skills indicators.

\section{B. Method of Data Analysis}

The data already obtained will be analyzed descriptivelyquantitative. This method is used to describe premises clearly how the scores obtained by students for each indicator of academic skills without any influence given first by the researchers, the existing data obtained is the actual data that occurred in the field. To get a good research then required precision in the analysis process.

\section{RESULT AND DISCUSSION}

Subjects used in this study were 35 students, 35 students tested their life skills that focused on three indicators of academic skills. This indicator is measured using a questionnaire instrument containing 6 statements. Statements are used to measure the ability to identify and connecting variables, mastering knowledge, and thinking strategically of students. Table 1 shows the average of the students' academic skills of life skills.

TABLE I. LIFE SKILL INDICATORS OF STUDENTS' ACADEMIC SKILLS

\begin{tabular}{|l|c|c|}
\hline \multicolumn{1}{|c|}{ Indicator } & Average & Category \\
\hline Identify and connecting variables & 2.90 & Medium \\
\hline Mastering knowledge & 2.79 & Medium \\
\hline Thinking strategically & 3.26 & High \\
\hline
\end{tabular}

Table I shows that the average indicator of strategic thinking is higher than the two other indicators, which has an average of 3.26 with high category. The category can be stated low if the average score of 1-1.99, while if the average score 22.99 , and high if the average score of 3-4.

\section{TABLE II. FREQUENCY OF STATEMENT 1}

Identify and connect variables (LSMM1)

\begin{tabular}{|c|c|c|c|c|c|}
\hline & & Frequency & Percent & Valid Percent & $\begin{array}{c}\text { Cumulative } \\
\text { Percent }\end{array}$ \\
\hline \multirow[t]{5}{*}{ Valid } & 1 & 2 & 5.7 & 5.7 & 5.7 \\
\hline & 2 & 4 & 11.4 & 11.4 & 17.1 \\
\hline & 3 & 14 & 40.0 & 40.0 & 57.1 \\
\hline & 4 & 15 & 42.9 & 42.9 & 100.0 \\
\hline & Total & 35 & 100.0 & 100.0 & \\
\hline
\end{tabular}

Table II shows that the students who received the highest score (4) in the environmental problem statement came from the non-contaminated garbage piles as many as 15 students $(42.9 \%)$ of the 35 students who became respondents. This means that 15 students already have the ability to identify and connect good variables.

\section{TABLE III. FREQUENCY OF STATEMENT 2}

Identify and connect variables (LSMM2)

\begin{tabular}{|c|c|c|c|c|c|}
\hline & & Frequency & Percent & Valid Percent & $\begin{array}{c}\text { Cumulative } \\
\text { Percent }\end{array}$ \\
\hline \multirow[t]{5}{*}{ Valid } & 1 & 3 & 8.6 & 8.6 & 8.6 \\
\hline & 2 & 13 & 37.1 & 37.1 & 45.7 \\
\hline & 3 & 14 & 40.0 & 40.0 & 85.7 \\
\hline & 4 & 5 & 14.3 & 14.3 & 100.0 \\
\hline & Total & 35 & 100.0 & 100.0 & \\
\hline
\end{tabular}

Table III shows that students who received the highest score (4) on the statement of rice husk abundance and water hyacinth (Eichornia crassipes) will become garbage as many as 5 students $(14.3 \%)$ from 35 students who become respondents. This means that the 5 students already have the ability to identify and connect good variables.

TABLE IV. AVERAGE ON STATEMENTS 1 AND 2

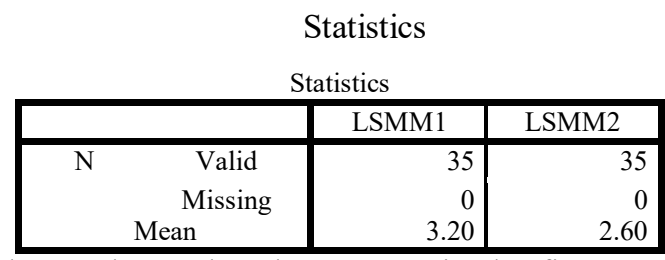

Table IV shows that the average in the first statement is 3.20 and the average of the 2 statements is 2.60 . Thus, the average indicator on identifying and linking variables is 2.90 with the moderate category. Broadly speaking, the indicators identify and connect the variables in the student self needs to be improved again.

TABLE V. FREQUENCY OF STATEMENT 3

Mastering knowledge (LSMP1)

\begin{tabular}{|c|c|c|c|c|c|}
\hline & & Frequency & Percent & Valid Percent & $\begin{array}{c}\text { Cumulative } \\
\text { Percent }\end{array}$ \\
\hline \multirow[t]{5}{*}{ Valid } & 1 & 2 & 5.7 & 5.7 & 5.7 \\
\hline & 2 & 19 & 54.3 & 54.3 & 60.0 \\
\hline & 3 & 11 & 31.4 & 31.4 & 91.4 \\
\hline & 4 & 3 & 8.6 & 8.6 & 100.0 \\
\hline & Total & 35 & 100.0 & 100.0 & \\
\hline
\end{tabular}

Table $\mathrm{V}$ shows that the students who received the highest score (4) on the briquette making material statement from rice husk and water hyacinth (Eichornia crassipes) were 3 students $(8.6 \%)$ from 35 students who became respondents. This means that 3 students already have the ability to master good knowledge. 
TABLE VI. FREQUENCY OF STATEMENT 4

Mastering knowledge (LSMP2)

\begin{tabular}{|c|c|c|c|c|c|}
\hline & & Frequency & Percent & Valid Percent & $\begin{array}{c}\text { Cumulative } \\
\text { Percent }\end{array}$ \\
\hline \multirow[t]{4}{*}{ Valid } & 2 & 4 & 11.4 & 11.4 & 11.4 \\
\hline & 3 & 22 & 62.9 & 62.9 & 74.3 \\
\hline & 4 & 9 & 25.7 & 25.7 & 100.0 \\
\hline & Total & 35 & 100.0 & 100.0 & \\
\hline
\end{tabular}

Table VI shows that students who received the highest score (4) in the initial statement of knowledge about briquette making were 9 students $(25.7 \%)$ of 35 students who became respondents. This means that the 9 students already have the ability to master good knowledge.

\section{TABLE VII. AVERAGE ON STATEMENTS 3 AND 4}

\section{Statistics}

\begin{tabular}{|c|c|c|c|}
\hline & & LSMP1 & LSMP2 \\
\hline \multirow[t]{3}{*}{$\mathrm{N}$} & Valid & 35 & 35 \\
\hline & Missing & 0 & 0 \\
\hline & Mean & 2.43 & 3.14 \\
\hline
\end{tabular}

Table VII shows that the average of the 3 statements is 2.43 and the average of the 4 statements is 3.14 . So, the average on the indicators mastered the knowledge of 2.79 with the medium category. Broadly speaking, the indicators of mastering knowledge in students need to be improved again.

\section{TABLE VIII. FREQUENCY OF STATEMENT 5}

Thinking strategically (LSBS1)

\begin{tabular}{|rc|r|r|r|r|}
\hline & & & & \\
& & Frequency & Percent & Valid Percent & $\begin{array}{c}\text { Cumulative } \\
\text { Percent }\end{array}$ \\
\hline Valid & 2 & 7 & 20.0 & 20.0 & 20.0 \\
& 3 & 21 & 60.0 & 60.0 & 80.0 \\
& 7 & 20.0 & 20.0 & 100.0 \\
& & 7 & 100.0 & 100.0 & \\
\hline
\end{tabular}

Table VIII shows that students who received the highest score (4) in the waste recycling statement became useful as many as 7 students $(20.0 \%)$ of the 35 students who were respondents. This means that 7 students already have good strategic thinking skills.

\section{TABLE IX. FREQUENCY OF STATEMENT 6}

Thinking strategically (LSBS2)

\begin{tabular}{|c|c|c|c|c|c|}
\hline & & Frequency & Percent & Valid Percent & $\begin{array}{l}\text { Cumulative } \\
\text { Percent }\end{array}$ \\
\hline \multirow[t]{4}{*}{ Valid } & 2 & 2 & 5.7 & 5.7 & 5.7 \\
\hline & 3 & 13 & 37.1 & 37.1 & 42.9 \\
\hline & 4 & 20 & 57.1 & 57.1 & 100.0 \\
\hline & Total & 35 & 100.0 & 100.0 & \\
\hline
\end{tabular}

Table IX shows that students who received the highest score (4) in the recycling statement of rice husk and water hyacinth (Echornia crassipes) became something of a quality and economic value as much as 20 students (57.1\%) of 35 students who became respondents. This means that 20 students already have good strategic thinking skills.

\section{TABLE X. AVERAGE ON STATEMENTS 5 AND 6}

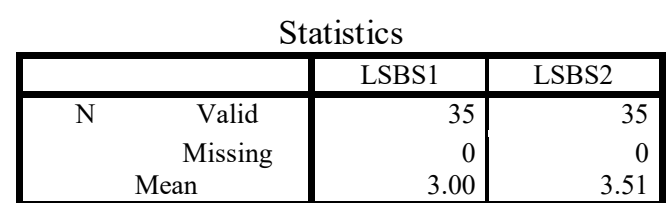

Table $\mathrm{X}$ shows that the average in the 5 statement is 3.00 and the average in the 6 statement is 3.14. So, the average on the indicators mastered the knowledge of 3.51 with high category. Broadly speaking, although the indicators of strategic thinking are already high but these indicators need to be improved again in students themselves in order to score the maximum.

From the overall data above shows that the indicators of academic skills in students still need to be improved again. In order for these indicators to increase in students, there are various ways to develop academic skills, such as practicum (Newell-Jones et al, 2005) or with project-based tasks, such as practicum or projects on topics that can assist in developing academic skills such as environmental change and waste recycling. When students study changes or environmental problems students may have a sense of concern for the environment, such as Baldassare \& Katz (1992) and SGuin, Pelletier, \& Hunsley (1998) suggest that the threat posed by changes or environmental problems can have an impact to motivate students to mitigate the problem, education on waste issues and raising public awareness about recycling is a top priority so awareness of waste issues is increasing (DETR 2000).

Teachers or parties involved in student education it is necessary to select and develop effective resolution methods in solving a problem (Kilpatrick, Swafford \& Findel 2001), such as involving the surrounding environment into learning theory, the environment can be used as a learning medium that is perceived to be able to assist students in understanding the material because in general the students know and experience it themselves, or give the project task to solve a problem, such as environmental problems caused by the existence of husk rice and water hyacinth (Eichornia crassipes) are abundant. To be able to reduce the existence of rice husk and water hyacinth (Eichornia crassipes) that abundant can be done by recycling process into something useful like briquette.

The process of recycling rice husk and water hyacinth (Eichhornia crassipes) can be done through project-based learning, because with such learning the students will be directly involved in problem solving, the students themselves who decide how to approach the problem and what activities will be used to pursue the solution (Weber, 2016). Projectbased learning can train and develop life skills (Wurdinger \& Qureshi, 2014). With project-based learning in a learning activity is expected to create meaningful, memorable and easily understood learning by students because of their involvement in problem solving (Herawan \& Rahayu, 2015). 


\section{CONCLUSION}

Based on the results outlined above it can be concluded that the ability to identify and connecting variables included in the category medium with an average of 2.90 , the ability to mastering knowledge included into the category of moderate with an average of 2.79 , while the ability to thinking strategically into the high category with an average 3.26. In order for the three indicators of academic skills to increase within students, then when providing theory or knowledge to students should involve the surrounding environment in general the students know or experience it yourself to be a teaching material or with the provision of project-based tasks for learning more meaningful. When learning is meaningful, then the learning will be stored in their long-term memory.

\section{ACKNOWLEDGMENT}

When doing research and preparation in making this paper, the authors get a lot of guidance and assistance from various parties. Therefore the authors would like to thank Dr. Hj. Widi Purwianingsih, M.Si as one supervising teacher who always guide the writer patiently. Dr. Yayan Sanjaya, M.Si as a twotime supervisor who always guide the writer patiently. A family that always gives support. Helpful friends.

\section{REFERENCES}

[1] Anwar. (2004). Pendidikan kecakapan hidup. Bandung: Alfabeta.

[2] Association for Career and Technical Education (ACTE). What is "Career Ready"?. www.acteonline.org.

[3] A. Bandura, "Social learning theory," Prentice-Hall, Inc., New Jersey, 1977.

[4] Baldassare, M., \& Katz, C. (1992). The Personal Threat of Environmental Problems as Predictor of Environmental Practices. $\begin{array}{lll}\text { Environment and } & \text { Behavior, }\end{array}$ https://doi.org/10.1177/0013916592245002

[5] Cronin, M. E. (1996). Life Skills Curricula for Students with Learning Disabilities: A Review of the Literature. Journal of Learning Disabilities, 29(1), 53-68. https://doi.org/10.1177/002221949602900108

[6] Departemen Pendidikan Nasional. (2003). Life skills-pendidikan kecakapan hidup.

[7] DETR. (2000). Waste Strategi 2000 The Stationary Office, London

[8] Fati, L., Motabi, F., Mohammadkhani, Sh., Bolhari, J., and Kazemzadeh, O. M. (2006). Life Skills Training for Student: Tutor Handbook. Danjeh Publication, Tehran

[9] Gamble, B. (2006). Teaching Life Skills for Student Succes. Technique. 81(6): 40-41.

[10] Herawan, E., \& Rahayu, L. (2015). Pengaruh aktivitas belajar siswa dalam penerapan model.

[11] Jabeen, S., \& Khan, M. A. (2013). A study on Creative Thinking Abilities and Self-Concept of High and Low Achievers. Journal of Education Practice, 4(4), 225-235.

[12] K. Junge, S., Manglallan, S., and Raskauskas, J. (2003). Building Life Skills through Afterschool Participation in Experiential and Cooperative
Learning. Child Study Journal. State University of New York at Buffalo. HighBeam Research. 16 Jul. 2018 Retrieved from https://www.highbeam.com.

[13] Kilpatrick, J., Swafford, J., and Findel, B. (2001). Adding it Up: Helping Children Learn Mathematics", Washington, DC: National Academy Press.

[14] L. Dailey, A., A. Conroy, C., \& A. Shelley-Tolbert, C. (2001). Using Agricultural Education As The Context To Teach Life Skills. Journal of Agricultural Education, 42.

[15] Lagat, G. (2017). Life Skills Education Curriculum Implementation: Appropriateness Of Teaching Methodologies Used By Secondary School Teachers In Uasin Gishu County, Kenya, 5(4), 86-95.

[16] Newell-Jones, K., Osborne, O., \& Massey, G. (2005). Academic Skills Development-Changing Attitudes through a Community of Practice. Brookes eJournal of Learning and Teaching, volume 1(2). Retrieved from http://bejlt.brookes.ac.uk

[17] Prapajati, S., \& Sharma. (2017). Significance Of Life Skills Education. Contemporary Issues in Education Research - First Quarter, 10(1), 1-6. Retrieved from https://files.eric.ed.gov/fulltext/EJ1126842.pdf

[18] Print, M. (1993). Curriculum development atid design. Sydney, Australia, Allen anfd Ulwin Co.

[19] Pusat Kurikulum Depdiknas. (2006). Penerapan model pendidikan kecakapan hidup. Jakarta: Balitbang Depdiknas.

[20] R Burchinal, M., Peisner-Feinberg, E., Pianta, R., \& Howes, C. (2002). Development of Academic Skills from Preschool Through Second Grade: Family and Classroom Predictors of Developmental Trajectories. Journal of School Psychology, 40, 415-436.

[21] Sarwar, M., Bashir, M., Khan, M. N., \& Khan, M. S. (2009). Studyorientation of high and low academic achievers at secondary level in Pakistan. Educational Research, 4(4), 204-207.

[22] Saylor, J., Alexander, W., \& Lewis, A. (1981). Curriculum planning for better teaching and learning (4th ed.) New York: Holt, Rinehart \& Winston.

[23] SGuin, C., Pelletier, L. G., \& Hunsley, J. (1998). Toward a Model of Environmental Activism. Environment and Behavior, 30(5), 628-652. https://doi.org/10.1177/001391659803000503

[24] Subasree, R., \& Nair, A. R. (2014). The Life Skills Assessment Scale the construction and validation of a new comprehensive scale for measuring Life Skills ., 19(1), 50-58.

[25] Taba, H. (1962). Curriculum development theory and practice," San Fransisco, CA: San Fransisco College Press.

[26] Trigwell, K., and Prosser, M. (1991). Improving the quality of student learning: The influence of learning context and student approaches to learning on learning outcomes. Source: Higher Education Higher Education, 22(22), 251-266. https://doi.org/10.1007/BF00132290

[27] [27] Tuttle, Campbel-Heider, D. (2004). Positive adolescents life skills training for high-risk teens: Result of a Group Intervention Study.

[28] [28] Tyler, R. W. (1949) "Basic principles of curriculum and instruction", Chicago, The University of Chicago Press.

[29] Weber, B. (2016). The Effectiveness of Participation in a Project-based Learning Project on At-risk Student Self-Efficacy. https://doi.org/10.15760/etd.3322

[30] World Health Organization. (1997). Life skills education in schools. WHO/MNH/PSF/93.7A.Rev.2.

[31] Wurdinger, S., \& Qureshi, M. (2014). Enhancing College Students' Life Skills through Project Based Learning. Innovative Higher Education, 40. 